ELOHI

Peuples indigènes et environnement

4 | 2013

L'invention de l'indigène écologiste

\title{
R.L. Stevenson's Kidnapped: indigenousness begins at home
}

Nathalie Jaëck

\section{(2) OpenEdition}

Journals

\section{Electronic version}

URL: http://journals.openedition.org/elohi/565

DOI: 10.4000/elohi.565

ISSN: 2268-5243

\section{Publisher}

Presses universitaires de Bordeaux

\section{Printed version}

Date of publication: 1 July 2013

Number of pages: $61-75$

ISBN: 978-2-86781-927-8

ISSN: 2431-8175

\section{Electronic reference}

Nathalie Jaëck, « R.L. Stevenson's Kidnapped: indigenousness begins at home », ELOHI [Online], 4 | 2013, Online since 01 July 2014, connection on 01 May 2019. URL : http://journals.openedition.org/ elohi/565 ; DOI : 10.4000/elohi.565 


\section{R.L. Stevenson's Kidnapped: indigenousness begins at home.}

NATHALIE JAËCK

E.A. CLIMAS, Université Bordeaux-Montaigne

It might seem to take a taste for paradox to elect Kidnapped, one of Stevenson's most deeply Scottish novels, to exemplify his stance with indigenous peoples and the environment.

After a life of traveling, Stevenson eventually settled in Samoa and ended his life there, becoming a staunch supporter of the Samoan desire for home rule and a defender of their rights, and endearing himself to the natives who called him Tusitala, "the teller of tales;" studying The Ebb-Tide or the In the South Seas where he explicitly condemns European colonial exploitation could thus seem the more obvious choice, and re-rooting indigenousness in Scotland might appear quite ironically ethnocentric. ${ }^{1}$ And yet, Stevenson's later explicit

1. Oliver Buckton sums up the fact, which is now well-documented in Stevenson criticism: "His later South Seas writings are far more trenchant in their use of evidence on the devastating impact of colonialism on indigenous peoples and cultures" (30). Yet, critics have recently concentrated on the links between Scotland and Samoa in Stevenson's experience and fiction, particularly as far as his analysis of imperial domination is concerned. As he himself developed in In the South Seas, he could find in the Samoan situation a new efficient paradigm to look back upon and reassess the situation of imperial domination imposed upon Highlanders. In Robert Louis Stevenson in the Pacific: Travel, Empire, and the Author's Profession, Roslyn Jolly defines Catriona, the sequel to Kidnapped Stevenson published seven years later when he had settled in Samoa, as "a much more intellectual as well as a more political novel than Kidnapped" (119), and she carefully documents the fact that "critical interest in the 'cross-fertilization' between Stevenson's Pacific experiences and his Scottish fiction has tended to focus on comparisons between A Footnote to History and Catriona." (119). She insists that Catriona's "actual working out in both conceptual and psychological detail was significantly affected by Stevenson's exposure to Pacific cultures between 1888 and 1892, and more particularly by his political experiences in Samoa in 1991-1992." (Jolly: 121) The reader can be referred here to Jolly's exhaustive note $\mathrm{n}^{\circ} 20$, p. 121 , where she fully refers to these pieces, quoting in particular Letley's introduction to Catriona, where he identifies the similarities between Catriona and A Footnote to History as far as the colonial situation is concerned. Oliver Buckton engages in a similar extensive comparison between the two books, and places it in the context of a broader assessment of the two countries' separate colonial histories. He explicitly elects Catriona as the more adequate novel for the comparison, arguing that the atmosphere of the novel is "dramatically altered" from Kidnapped, and "stems from Stevenson's observations of Samoan colonial politics" (202). Yet, I would like to follow in the quite alternative steps of Barry Menikov who, in Narrating Scotland, pointed out that as early as Kidnapped, published in 1886, Stevenson commented upon his country's loss of indigenous culture, and linked the conflicts between the Highlands and the Lowlands to a political context that had much to do with imperial domination. 
preoccupation with the issue, and more specifically with the link between indigenousness and territorial claims, is much closer to the bone, rooted in the history of his Scottish homeland.

Kidnapped is set in the Scottish Highlands in 1751, in a context of authoritative English occupation of the territory following the heavy defeat of the Jacobites at the battle of Culloden in 1746. I would like to prove in this paper that the novel can be read as a documented denunciation of what is forcefully described as an imperialist situation, based on the same politics of clearances and proscription that were implemented in overseas colonies: Kidnapped is an act of literary and political resistance, an alter-version of history reclaiming territorial possession for those (not so) "wild Highlanders" (101). ${ }^{2}$

It is the story of an unlikely friendship between young and naive David Balfour of Shaws, a Whig Lowlander by family tradition but whose personal political positions are rather unsettled, and who cautiously defines himself as "betwixt and between" (60), and Alan Breck Stewart, a dashing and unwavering Jacobite Highlander and outlaw, a fervent and heroic supporter of Bonnie Prince Charlie. After a few personal incidents involving being kidnapped by his uncle who does not want him to inherit the family fortune and who treacherously embarks him on a boat bound for the colonies, David meets Alan on the boat, after he was rescued, the only survivor, from a sinking ship. There happens to be another convenient shipwreck allowing the two men to escape from the unscrupulous crew, and the better part of the novel then consists in David's and Alan's wandering flight across the Highlands in order to return safely to Edinburgh and redeem David's property while escaping the vigilance of the Red Coats that swarm the country after the murder of Colin Campbell, the Red Fox.

David is the first-person narrator, and as he meets with natives and travels their lands under the masterful guidance of Alan, he is led to reassess his mildly patronising and stereotypical vision of those supposedly uncivilized indigenous clan peoples, and thus to question the politics of domination of Britain, gradually coming to link them to practises of cultural and economic imperialism. But beyond these elements of denunciation, Kidnapped also crucially constitutes a symbolical act of territorial re-appropriation (a political parallel to the personal embedding story indeed, since Kidnapped is explicitly the story of an illegal expropriation and the efforts of the young hero, David, to reclaim his property): not only do David and Alan outwit the English occupant through Alan's superior intimate knowledge of the ground, and walk over the territory,

2. All the references to the novel will be to the following edition: Robert Louis Stevenson, Kidnapped, London: Penguin Classics, 1994 (1886). It is worth pointing out that Stevenson himself being a Lowlander, "the other" in terms of Highland culture, makes his capacity to plead the Highlanders' cause all the more remarkable. 
thus reclaiming their possession, but Stevenson comes up with a very strange map, at the outset of the story, as warning paratext. ${ }^{3}$

In this sketch of "the probable course of David Balfour's Wanderings", he totally subverts the contemporary use of the map as an instrument of power, as a major tool of colonisation: he empties it from any registration of English presence, ${ }^{4}$ he seems to return the land to a terra incognita, as he inscribes the map with Alan's and David's course only, and thus erases the marks of colonial history, restoring the territory to its legitimate if not legal owners. In his deconstructed and unauthoritative map, Stevenson disengages geography from power, ${ }^{5}$ the Highlands are back to an all-open territory, disencumbered from received constructions of political geographies and identities, for David and Alan to explore freely and take over.

The first point to make clear is that in Kidnapped, Stevenson depicts the Highlands as a colonized territory, and intimates that the same rhetoric as for the native peoples of overseas colonies was used to define savage Highlanders, both by the English, and by supposedly more civilized Lowlanders. Such a vision was indeed quite common at the time, as is developed by Colin Calloway in his book "White People, Indians, and Highlanders": Tribal Peoples and Colonial Encounters in Scotland and America" where he "examines the common ground

3. As Stevenson explains in his "Note to the map", he gave very minute instructions to his cousin, David Stevenson, who designed the map. He was very specific about several quite disquieting elements: "the line must be sometimes dotted to show uncertainty; sometimes full" (xxiv) - as if some parts of this fictive itinerary were more fictive than others; he also insisted that the final stage of David's journey should be off the limits of the map, in its unregistered margins, as if to highlight the fact that no representation is ever exhaustive: "The line (full again) descends Balquhidder from the top, turns down Strathire, strikes over Uam Var, hits Alan Water above Kippendaire, descends Alan Water to the Forth, along the N. bank of Forth to Stirling bridge, and by road by Alloa, Clackmannan and Culross, till it issues from the map; for I fear we don't reach Limekilns; which we really should have done, for from that point my hero crosses the Forth to Cawiden, and thence to Queensferry. Terminus Malorum. (xxi) The map the reader is suggested to pore over before embarking on the reading is thus no ordinary illustrative map: its function is to insist on some formal dissident characteristics of the text, by being quite a dissident map itself. The full text of this letter to his cousin can be found in the Yale edition of R.-L. Stevenson's letters (vol. V, pp. 230-1).

4. The map represents a land untouched by English interference: specifically, the English general Wade did build roads throughout the Highlands in the early $18^{\text {th }}$ century thus making the territory more accessible to government troops - and these roads are erased from the map, denied any reach on the territory.

5. Said showed how much in mapping "territory and possessions are at stake, geography and power" (5).

6. Calloway borrows his title from the founder of Georgia, James Oglethorpe, who raised a motley army of what he called "white people, Indians and Highlanders" to fight against Spanish Floridians when war broke out in the 1730s between Britain and Spain: "In the 1730s the trustees of Georgia recruited Highlanders from the North of Scotland to serve as farmers-soldiers on the frontier against the Spaniards and Indians in Florida. [...] The Highlanders spoke Gaelic, wore kilts and wielded broadswords" (xiii). 
that Highlanders and Indians shared as tribal people living on the edge of an English-speaking Atlantic world, considering the ways in which colonialism reconstructed histories and images of Highlanders and Indians, histories and memories of oppression and resistance" (xiii). He documents the fact that "pairing American Indians and Celtic Highlanders together as non-whites made sense to $18^{\text {th }}$ century Englishmen, as it did to many Scottish Lowlanders" (xiii). Indeed, they used kinship (clans or tribes) to structure their communities in a system that seemed quite primitive to the English, they managed the land communally and developed a similar kind of intimate relationship to it, they maintained warrior traditions; they also had quite convergent historical experiences, living at the borders of an expanding empire and having to fight the British assaults against their autonomy, culture and land. The same derogatory terms were applied to them, "they were routinely described as wild, savage, barbarous, primitive, lawless, warlike, treacherous, vengeful, lazy, dirty, poor, superstitious and always in need of instruction and improvement. They were the tribal peoples who inhabited the Northern frontier of Great-Britain and the Western frontier of North America" (3).

So there is clearly no paradoxical stretch in considering Scottish Highlanders as indigenous peoples undergoing colonial oppression. Stevenson himself, in his many travels overseas, noticed a parallel between the South Sea Islanders and the "barbaric" Highlanders, as he develops in In the South Seas, where he notices "points of similarity between a South Sea people and some of my own folk at home" (23). In the beautiful second chapter, "Making Friends," he characterizes these similarities and the sense of kinship he thus immediately felt with the Marquesans:

It was perhaps yet more important that I had enjoyed in my youth some knowledge of our Scots folk of the Highlands and the Islands. Not much beyond a century has passed since these were in the same convulsive and transitionary state as the Marquesans of to-day. In both cases an alien authority enforced, the clans disarmed, the chiefs deposed, new customs introduced, and chiefly that fashion of regarding money as the means and object of existence. The commercial age, in each, succeeding at a bound to an age of war abroad and patriarchal communism at home. In one the cherished practice of tattooing, in the other a cherished costume, proscribed. In each a main luxury cut off: beef, driven under cloud of night from Lowland pastures, denied to the meat-loving Highlander; long-pig, pirated from the next village, to the man-eating Kanaka. The grumbling, the secret ferment, the fears and resentments, the alarms and sudden councils of Marquesan chiefs, reminded me continually of the days of Lovat and Struan. Hospitality, 
tact, natural fine manners, and a touchy punctilio, are common to both races: common to both tongues the trick of dropping medial consonants. (23-24) ${ }^{7}$

In Kidnapped, Stevenson uses David, a kind of naive representative, to voice the widespread stereotypes about a supposedly barbaric nature, at the beginning of the novel - before he actually gets to explore the Highlands in more detail, and to challenge his own representations.

Indeed, David's descriptions of Highlanders are often typical of the prejudices of the age: primitive, animal-like, childish and uncouth, notably in their speaking English with a strong accent and rather irregular grammar that Stevenson makes a point of inscribing, marking his text with non-standard spellings and grammar that closely shadows their native Gaelic. Their social organisation strikes David as primitive: feudal "clansmen", "chieftains" and "chiefs" seem to have replaced the intricate social hierarchy of the English society, and David, just like Hoseason the captain of the boat, uses the category of "wildness" or "savagery" to account for these modes of organisation: "yon wild hielandman" (61), "savage" $(111,148)$. Wildness is best transcribed by a proximity between Highlanders and animals, and animalising metaphors abound: Alan is said to be "as nimble as a goat" (57), "a bull, roaring as he went" (68), "a sheepdog chasing sheep" (68), "a fair heather-cat" (112), "a hare" (154). He runs on all fours ("he began to run forward on his hands and knees with an incredible quickness, as though it were his natural way of going" (154)), while Ardshiel "has to flee like a poor deer upon the Mountain" (81). Basically all the Highlanders find shelter in nature that seems to be pierced with so many burrows to accommodate these in-between creatures, Cluny, one of the chief clansmen living in "caves" (159), their houses literally carved in nature. Despite Alan's obvious superiority over David, his always leading the way, taking initiative, basically guiding David all the way through, David cannot help patronizing flamboyant Alan, typically degrading competence and bravery either to immaturity or to irrationality. Immediately after Alan has once more saved their lives and proved a master swordsman, killing four enemies all by himself, David reduces his feat to childish excitement, belittling him: "All the while, the flush was in his face, and his eyes were as bright as a five-year-old child's with a new toy." (69) When he first meets him, and though once more Alan has just saved the day, it is a picture of dark savagery and madness that David conjures up: "He was smallish in stature, but well-set and as nimble as a goat; his face was of a good open expression, but sunburnt very dark and heavily freckled and pitted with the smallpox; his

7. About the natives of Little Makin, Stevenson adds: "They are said to be more savage, and to be proud of the distinction. Indeed, it seemed to us they swaggered in the town, like plaided Highlanders upon the streets of Inverness, conscious of barbaric virtues" (75). 
eyes were unusually light and had a kind of dancing madness in them." (57) Alan seems to concentrate all the traits of the savage here: smaller in stature as virtually all the savages in fiction, height being a sign of further evolution, animal-like, seemingly genial but potentially irrational and mad, with a kind of subliminal reference to sensuous primitive dancing - and obviously the suntan conveniently making him "a non-white".

Stereotypes are obviously hard to die, and much later in the novel, David's description of John Breck is another instance of an intensive version of the stereotype, merging together savagery, weakness, childishness, idiocy, disease and grossness: "He was a ragged, wild, bearded man, about forty, grossly disfigured by smallpox, and looked both dull and savage. [...] His English was very bad and broken. [...] Perhaps the strange language made him appear more backward than he really was; but I thought he had little good-will to serve us, and what he had was the child of terror." (148) The collective portrait generalizes these particular cases, and David's collocations are quite telling: "The inn at Kinlochaline was the most beggarly vile place that ever pigs were styed in, full of smoke, vermin, and silent Highlanders" (110) - the dominant superlative form, the assimilation of Highlanders to a place full of vermin, and thus to a rampant, collective noxious species, the lowest one on the scale of evolution, and finally the absence of rational language all point at the Highlanders' primitivism.

Stevenson makes it clear that such mundane degrading and fantasized representations of the Highlanders, as they are naively voiced without any animosity by David, served as implicit justification for the colonial and imperial ideologies and plans: education and betterment were thus deemed a matter of duty from a more civilized people. ${ }^{8}$ As was the case in British colonies, "catechists" were then "sent out by the Edinburgh society for propagating Christian knowledge, to evangelize the more savage places of the Highlands" (111). In Kidnapped, the name of the missionary is Henderland, and Stevenson thus made it clear that beyond the philanthropist alibi, the primary aim of such interventions was indeed to cleave, to split, to break the land, to establish control over a territory and increase political and economic ascendency. He draws a rather damning collective account of British occupation, coming not only from obviously bi-

8. Francis Jennings explains that the English have historically applied the category of "savagery" to the Irish in exactly the same way: "In 1395, Richard II of England excoriated the 'wild' Irish who maintained independence of his rule. 'Wild Irishman' is a humorous phrase nowadays, but Richard was not making jokes, and neither were his officials in Ireland who used the term repeatedly and who hanged those Irishmen when they caught them. 'Wild Irish' is really a translation from the Norman-French used by the conquest aristocracy. The words actually written by Richard were 'irrois savages, nos enemis' literally 'savage Irish, our enemies.' In an era of linguistic mixing, the words 'wild' and 'savage' were used interchangeably not only to identify Irish people but also to describe the Scots of the highlands and the islands, contrasting them with the Anglicized inhabitants of the lowlands" (7). 
ased Alan, but also from the missionary himself, and denounces the politics of clearances and proscription imposed upon the Highlands.

In his initial account, Alan insists that the English targeted both their lands and culture: "The English rogues [...] were striking at his rights. They stripped him of his powers; they stripped him of his lands, they plucked the weapons from the hands of his clansmen, that had borne arms for thirty centuries; ay, and the very clothes off their backs - so that it's now a sin to wear a tartan plaid, and a man can be cast into a gaol if he has but a kilt about his legs" (81). Henderland confirms Alan's analysis, insisting that the English not only strived at "pacifying the Highlands" (108) after the rebellion, but above all at destroying the alternative culture and identity of the country, and also at depriving the crofters of their lands: they confiscated them and put them out for rent, intending that richer Lowlanders would outbid the impoverished Highlanders that were subjected to heavy taxation (the more so since many of them also willingly contributed to financing Bonnie Prince Charles): "He seemed moderate: blaming Parliament in several points, and especially because they had framed the Act more severely against those who wore the dress than against those who carried weapons" (111). Along with Alan he confirms that "[Red Colin] would drive them out. Therefore he sent for lawyers, and papers, and redcoats to stand at his back. And the kindly folk of that country must all pack and tramp, every father's son out of his father's house, and out of the place where he was bred and fed." (83)

Indeed, three specific acts enforced the colonial policy: the 1715 Disarming Act that had been voted as a consequence of the Jacobite rebellion was heavily reimposed after Culloden, and the possession of Highland dress or even bagpipes was outlawed upon pain of transportation - David notices indeed, in the mouth of Loch Aline, "an emigrant ship bound for the American colonies" (108), and Stevenson documents the fact that "to carry (a pistol) meant a fine of fifteen pounds sterling upon a first offence, and transportation to the colonies upon a second" (104). The attempt to impose cultural imperialism in the Highlands was made more specific in the 1747 Act of Proscription that aimed at destroying the clan system, banning the wearing of Tartan and Highland dress: "A process known as proscription was set in place to take the heart out of traditional Highland culture while leaving many outward structures intact for administrative purposes. Under other names, 'civilisation', 'education', 'Christianisation', it was to become a cornerstone of colonial policy around the world" (McIntosh et al 7). As David comes to realize, "the law was harshly applied, in hopes to break up the clan spirit" (102). Finally, the movement of punitive

9. In 'White People, Indians, and Highlanders': Tribal Peoples and Colonial Encounters in Scotland and America, Colin Calloway details in a fascinating way the encounters between Highlanders and Native Americans in America, intermarriages and many types of collaborations and similarities. 
territorial eviction that is hinted at in Kidnapped was going to be intensified from 1785 by the enactment of a methodical policy of Highland Clearances, the forced and often brutal eviction of a significant number of native crofters, who were year-by-year tenants, through a policy of privatisation of the land which was said to be aiming at agricultural revolution. The generalisation of the policy of enclosures was carried out by aristocratic Scottish landowners, supported by the British government, ${ }^{10}$ in order to empty the centre of the country to favour sheep breeding and monoculture, that was deemed more profitable than diversified farming for subsistence and self-sufficiency, and to relegate the population to the coast, where workforce was needed for fishing. ${ }^{11}$ Stevenson's depiction of the workings of the colonial imposition is thus quite thorough: the light adventure novel becomes a site of denunciation and resistance, the aim of which is going to be to unwrite these disparaging representations of indigenousness, and to re-empower the natives, symbolically returning their territory to them.

As David is gradually initiated into the history of the Highlands, the novel proposes a radical deconstruction of the stereotypes, an elaborate dissolution of fantasized dichotomies - civilized vs. savage, strong vs. weak, manly vs. feminized are all reinterpreted through David's vision of Alan and his relationship to his own environment, which leads him to state: "If these are the wild Highlanders, I could wish my own folk wilder" (101).

The first element of the deconstruction is that Alan belongs to both nature and culture, he is both extremely adapted to his environment, and by far the most "civilized" character according to the criteria of the times. He definitely escapes $18^{\text {th }}$ century dominant paradigms; he is both "come of kings, bearing a king's name" (64) and "a heather-cat" (112).

When David meets Alan, he is immediately impressed by his civilized appearance and impeccable manners: compared with the crew of the boat and himself, who wear very ordinary clothes, Alan "showed forth mighty fine for

10. "The British government was, therefore, able to pursue its policies of cultural marginalisation not by expropriating the traditional Highland aristocracy but by incorporating the more powerful members of the clan figuration within the Hanoverian hegemony" (McIntosh et al 8).

11. In 1751, the time of the story, that process was just starting and was not yet led as a method for territorial deprivation. But when Stevenson actually wrote the story in 1886, it had been forcefully achieved, and had led to much bitterness in the Highlands, which obviously made contemporary readers quite aware of the consequences of the policies described in Kidnapped. An extremely well-documented account of that systematic policy of colonial disempowerment of the Highlands can be found in Alastair McIntosh, Andy Wightman and Daniel Morgan, "The Scottish Highlands in colonial and Psychodynamic Perspective", in INTERculture, Montreal, Vol. XXVII: 3, Issue 124, 1994, pp. 1-36. 
the round-house of a merchant brig: having a hat with feathers, a red waistcoat, breeches of black plush, and a blue coat with silver buttons and handsome silver lace: costly clothes. [...] His manners, besides, were elegant, and he pledged the captain handsomely"12 (57). The initial impression is confirmed later by the discovery of his many accomplished skills that reduce Lowland David, presumably more enlightened, to a very unrefined youngster. He is an expert swordsman; as opposed to David who is beyond his depth as soon as anything other than English is spoken, he is a rather learned linguist - he has got some Latin, some French, and he obviously speaks perfect Gaelic and English; he is well-aware of the history of his country and the stakes of the political situation; he is a good singer, a poet and a musician, able to play several instruments, but also to compose songs and poems as he fights his enemies: "He kept humming and singing and whistling to himself, like a man trying to recall an air; only what he was trying, was to make one" (69). But the achievement that most impresses David is his intimate knowledge of his environment, his being acutely aware of the geography around him - once more as opposed to the English occupants and David, for whom the Highlands are nothing but an inhospitable wilderness. David thus sees Alan's mastery of nature as another cultural skill, and the whole novel details this intimate knowledge.

For David, the Highlands "appeared to be a desert" (136), "a piece of low, broken, desert land" (152), "lying as waste as the sea" (153), "rugged and trackless" (100): "There may be roads for those that know that country well; but for my part, I had no better guide than my own nose" (100). He follows Alan blindly, totally unable to decipher the territory, which is as a "labyrinth of dreary glens" (158) to him: "But for the details of our itinerary, I am all to seek; our way lying now by shortcuts, now by great detours; and the names of such places as I asked and heard, being in the Gaelic tongue and the more easily forgotten" (136). As for the English troops, they fare no better in that blank space, where they can see only "bog, briar and big stone" (100): "no soldier would find the way that we came" (129), insists Alan. As opposed to them, Alan strikes David as totally integrated in his environment: what seemed to David barren nature is to Alan a bountiful multiple space, a reliable refuge, a source of abundant food, a hiding-place, basically satisfying all his needs. Typically, Alan is able to discriminate among the uniformity of the landscape, and to see through the opaque surface of heather, conjuring up a real Garden of Eden from the appearance of sterility and emptiness: "a cleft in the head of a great mountain, with

12. Of course, it would be fair to add that such a picture is also quite heavily romanticized, corresponding to the colourful, "picturesque" vision of the native populations Europeans typically had at the time: the red, blue, silver colours, plus the belt of gold he wears, the feathers in his hat, all point to a fantasized cheerful and juvenile taste for brightness, to be opposed to the stern attires of serious English protestants. 
a water running through the midst. Birches grew there in a thin, pretty wood. [...] The burn was full of trout; the wood of cushat-doves. [...] We slept in the cave, making our bed of heather bushes which we cut for that purpose" (145). The same goes for all the Highlanders able to "pass from island to island in all weathers, and by night too" (74); even a blind man can act as guide to David: "I know every stone and heather-bush by mark of head. See, now, down there a burn is running; and at the head of it there stands a bit of a small hill with a stone cocked upon the top of that" (105).

Above all, for Alan, the natural space of the Highlands is in fact a close cultural network of human links; wild nature is tightly netted with human presence, and Alan can rely upon furtive, undetectable knots of social solidarity, totally invisible to those who are not familiar with the topology of the land. Stevenson makes it clear that nature is inhabited indeed, that even if British rule tries to reduce the land to an expanse of vacant, unoccupied and thus available territory, a whole ancestral and communal culture thrives there, in the holes of the maps: "everywhere there are friends' houses and friends' byres and haystacks" (84), or "Though upon its face, the country appeared to be a desert, yet they were huts and houses of the people, of which we must have passed more than twenty, hidden in quiet places of the hills. When we came to one of these, Alan would leave me in the way, and go himself and rap upon the side of the house" (136).

This is precisely what makes the whole difference with the English troops: no matter how dense their criss-crossing of the land (the valley where David and Alan hide is "bristling with arms and dotted with the red coats and breeches" (140), "The Highlands are covered with troops and guarded like a city in a siege" (83)), their presence remains limited to the actual roads and tracks, to the official marking of the country, while the indigenous population walks across the territory, and appropriates the middle ground, escaping notice and registration. While the English can only enter the Highlands as what Deleuze called "un espace strié" (Deleuze \& Guattari 595), organized along and limited by a set of official lines that delimitate and strive to control the space, Highlanders consider it as "un espace lisse", to be explored freely and in all directions, irrespective of the official markings and limits. In between the roads where soldiers are stationed and thus quartered, there is a whole open space, beyond the mapped network, that is free for the natives to occupy freely, thus escaping the controlling vigilance of the Red Coats, as Alan explains to David:

A bare hillside (ye see) is like all one road; if there's a sentry at one place, ye just go by another. And then the heather's a great help. And everywhere there are friends' houses and friends' byres and haystacks. And besides, when folk talk of a country covered with troops, it's but a kind of a byword at the best. A soldier covers nae mair of it than his boot-soles. I have fished a water with a sentry on the other side 
of the brae, and killed a fine trout; and I have sat in a heather bush within six feet of another, and learned a real bonny tune from his whistling. (82)

While the soldiers are thus forced within pre-established organised ways, within territorialising lines, the population of the Highlands is highly rhizomatic, they imagine their own ever-changing lines of escape in a territory with multiple entrances and moving directions, like an ever-adaptable burrow. The territorial occupation is thus marked as a colonial delusion, the appropriation is rather limited - and it seems to me that Stevenson makes that point quite clear in deciding to open the novel with a very unorthodox map.

At the outset of the novel, Stevenson positions the following map (fig. 1), plus a note to the map in the form of a letter addressed to one of Stevenson's cousins, David A. Stevenson, who has undertaken to prepare a map illustrating the course of David's and Alan's wandering flight in the Highlands.

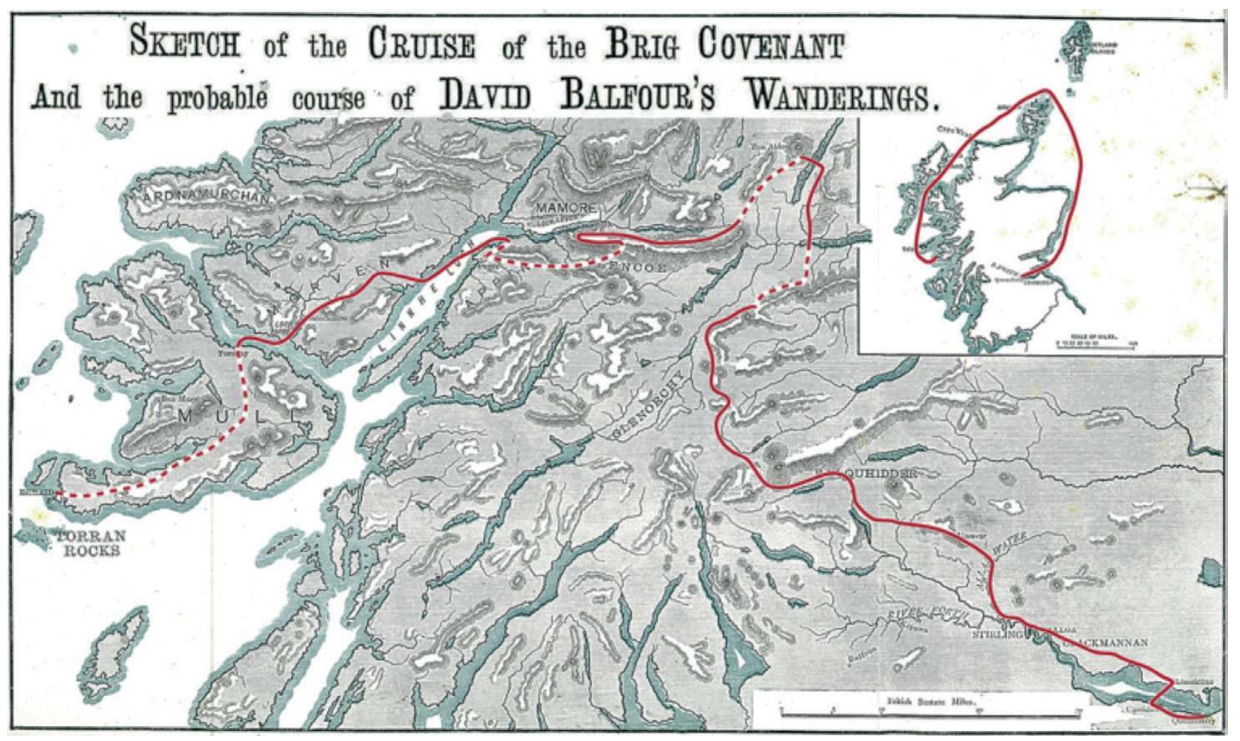

Figure 1: Kidnapped Sketch map, modified scan from Stevenson, Robert Louis (1895) [1886] Kidnapped, London: Cassell and Company (wikimedia commons)

In order to perhaps understand better the specificity of that particular map, it is interesting to remember the crucial role maps played throughout the $18^{\text {th }}$ and $19^{\text {th }}$ centuries to reinforce the colonial enterprise. In his book Mapping 
Men and Empire: a Geography of Adventure, Richard Phillips demonstrated how cartography was linked with the colonial enterprise, how mapping amounted for Europeans to imaginatively charting the world and materially possessing it: "The late nineteenth century scramble to map was also a scramble to colonise and consolidate imperial power. European imperialism and map-making reached a simultaneous climax at the end of the nineteenth century" (9). $\mathrm{He}$ developed the idea that cartographic maps had "a measure of authority, a power to naturalise constructions of geography and identity" (14) and shared this power with the typical Robinsonades that flourished at the time.

Now, just as Kidnapped is certainly not a typical adventure story celebrating colonial enterprise, British character and Victorian values of self-help, ${ }^{13}$ the map is no conventional map either. What is most remarkable is that it is a mere outline map inscribed only with the course of Alan's chosen random itinerary, and with the toponyms of the places they actually visit. Absolutely no trace of English appropriation is inscribed on the map, as if there could be no mastery of the land by those who do not belong, thus turning Kidnapped into a parody of typical adventure stories, starting from Crusoe, where the British hero is able to conquer the environment, to literally make himself at home in foreign lands, and to domesticate the natives. The place here, through the blank map, seems to be returned to its legitimate owners, as if the English had made absolutely no impact on the territory, as if their print were only superficial - thus ironically inverting a typical claim of the colonizers that they were taking over virgin lands. ${ }^{14}$ This is reminiscent of Conrad's famous beginning of Heart of Darkness:

Now when I was a little chap I had a passion for maps. I would look for hours at South America, or Africa, or Australia, and lose myself in all the glories of exploration. At that time there were many blank spaces on the earth, and when I saw one that looked particularly inviting on a map (but they all look that) I would put my finger on it and say, "When I grow up I will go there." [...] True, by this time it was not a blank space any more. It had got filled since my boyhood with rivers and lakes and names. It had ceased to be a blank space of delightful mystery - a white patch for a boy to dream gloriously over. It had become a place of darkness. (9)

In Stevenson's map, the land is returned to the mysterious terra incognita it used to be before English occupation. Instead of being an instrument of stabi-

13. I developed this point in Nathalie Jaëck, "To Jump or not to Jump: Stevenson's Kidnapping of Adventure." in Journal of Stevenson Studies. Vol. 6, 2009.

14. That dominant view is once more documented by Francis Jennings: "The basic conquest myth postulates that America was virgin land, or wilderness, inhabited by nonpeople called savages" (15). The whole chapter develops the point. 
lisation and control, the map becomes an invitation to wander, only inscribed with random directions. Quite tellingly, there is no legend either, and so no authoritative instruction to read the map, no hierarchy of information to further encode space and its exploration: we could say that it is a sort of map-in-progress, that highlights the fact that it is not stabilized, that it is no reference. In his note to his cousin, Stevenson specifies that the red line marking the itinerary "must be sometimes dotted to show uncertainty, sometimes full" (xxiv), thus insisting on the fact that because there is no fixed road to follow, because the protagonists need to cut across country, the line on a map is largely an arbitrary convention, inscribing the necessary gap between reality and its representation.

We thus come very close to Gilles Deleuze's ideal redefinition of the map, that he opposes to what he calls "tracing paper," "le calque," i.e. an over-coding structure, an institutional model of representation - a typical $19^{\text {th }}$ century map then, the aim of which was to register and celebrate the print on and the possession of the land, and to stabilize the representations of a country. In his map on the other hand, Stevenson chooses to reference the undefined Middle, to pick a course that is a temporary process defined by contiguity with the environment and that is directly influenced by random meetings or obstacles. There are no pre-existing roads on the map, no established or predetermined points, no choice destinations - only immanent, undifferentiated middle-ground, and as they trace an empirical way across that smooth nature David and Alan return the Highlands to a nomadic space, while the English want to make it sedentary, to restrain it through enclosures, stable divisions of space, to rationalize it. That makes all the difference between what Deleuze calls "un espace lisse" and "un espace strié": "Le strié, c'est ce qui entrecroise des fixes et des variables, ce qui ordonne et fait succéder des formes distinctes [...]. Le lisse, c'est la variation continue, c'est le développement continu de la forme, [...] le pur tracé d'une diagonale à travers la verticale et l'horizontale" (Deleuze \& Guattari 597). Indeed, the English try to methodically block the roads, to prevent Alan and David from going from one point to another: they trust what Deleuze calls "territorialisation lines" in an orthonormal space they think they can measure up and control. As opposed to them, Alan and David opt for anarchic development, deviations and discontinuities, carefully avoiding these territorialisation lines, the roads or even the smaller paths; they cut through the English plan, "hors des sillons coutumiers" (Deleuze 13), thus avoiding the static Red Coats, and turning the Highlands into a plateau, "une région continue d'intensités, vibrant sur elle-même et qui se développe en évitant toute orientation sur un point culminant ou vers une fin extérieure" (Deleuze \& Guattari 32): "We went down accordingly into the waste, and began to make our devious travel towards the eastern verge." (153), or "All the time, too, he kept winding in and out in the 
lower parts of the moorland where we were the best concealed. [...] Now and then, indeed, where there was a big bush of heather, we lay a while, and panted, and putting aside the leaves, looked back at the dragoons. They had not spied us, for they held straight on" (155).

So the red discontinuous line on the map is of course quite obviously "a line of escape" as Stevenson claims ("The improbability of the itinerary is not so great as it appears, for my hero was trying to escape - like all heroes..." (xxv)), but it seems to be above all a transversal highly dissident "deterritorialisation line," a way for indigenous Alan to symbolically dislodge the English occupant, to refuse to submit his own line to the English checkpoints: "Une ligne de devenir ne se définit ni par des points quelle relie, ni par des points qui la composent: au contraire elle passe entre les points, elle ne pousse que par le milieu, et file dans une direction perpendiculaire aux points qu'on a d'abord distingués" (Deleuze \& Guattari 359). As they cut across the heather, David and Alan trace a fictive line of resistance and Stevenson thus finds a way to use geography to unwrite histor $y^{15}$ and to enable indigenous Alan to re-appropriate the usurped territory of the Highlands.

\section{Works cited}

Buckton, Oliver. Cruising with Robert Louis Stevenson. Travel, Narrative, and the Colonial Body. Athens (USA): Ohio University Press, 2007.

Calloway, Collin. White People, Indians and Highlanders': Tribal Peoples and Colonial Encounters in Scotland and America. Oxford: OUP, 2008.

Colley, Ann C. Robert Louis Stevenson and the Colonial Imagination. Aldershot: Ashgate, 2004.

Conrad, Joseph. Heart of Darkness. London: Penguin, 1995 (1899).

Deleuze, Gilles \& Guattari, Félix. Mille Plateaux. Paris : Minuit, 1980.

Deleuze, Gilles. Critique et Clinique. Paris : Minuit, 1981.

JAËcK Nathalie. “To Jump or not to Jump: Stevenson’s Kidnapping of Adventure." in Journal of Stevenson Studies. Vol. 6, 2009.

Jennings, Francis. The Invasion of America: Indians, Colonialism, and the Cant of Conquest. New York: Norton, 1975.

Jolly, Roslyn. Robert Louis Stevenson in the Pacific: Travel, Empire, and the Author's Profession. Farnham and Burlington: Ashgate, 2009.

15. At the very beginning of his dedication of the novel to his friend Charles Baxter, Stevenson flippantly insists that he is taking liberties with history, arbitrarily deciding to misdate the Appin murder, the central historical event of the novel, and to capriciously situate it in 1751 instead of 1752: "If you ever read this tale, you will likely ask yourself more questions than I should care to answer: as for instance how the Appin murder has come to fall in the year 1751. [...] These are nuts beyond my ability to crack" (3). 
Mcintosh Alastair, Wightman Andy \& Morgan Daniel. "The Scottish Highlands in Colonial and Psychodynamic Perspective", in INTERculture, Montreal, Vol. XXVII: 3, Issue 124, 1994, pp. 1-36.

Menikov, Barry. Narrating Scotland: the Imagination of Robert Louis Stevenson. Columbia, South Carolina: University of South Carolina Press, 2005.

PhILIPS, Richard. Mapping Men and Empire: a Geography of Adventure. London: Routledge, 1996.

SAID, Edward W. Culture and Imperialism. London: Vintage, 1994.

Stevenson, Robert Louis. Kidnapped. London: Penguin Classics, 1994 (1886).

---. In the South Seas, Leipzig: Bernhard Tauchnitz, 1901.

Nathalie Jaëck is Professor of 19th century literature in Bordeaux-Montaigne University. She specializes in adventure literature, and particularly in the mutation of the genre that took place at the turn of the century. Her major interests are in narrative and formal analysis, popular literature, the Canon, and fin-de-siècle literature. She published several articles on Conan Doyle, Dickens, Stevenson, Conrad, Stoker, and two monographies: Les Histoires de Sherlock Holmes: une affaire d'identité. Bordeaux: Presses Universitaires de Bordeaux: 2008, et Charles Dickens: L'écriture comme pouvoir, l'écriture comme résistance. Bordeaux: Presses Universitaires de Bordeaux: 2008.

Abstract: In the present article, I illustrate the fact that Stevenson's well-known positions against imperialism as he developed them in In the South Seas when he was settled in Samoa, find a much earlier and much more surprising echo in Kidnapped, published in 1886. I would like to prove that this Scottish novel can be read as a documented denunciation of what is forcefully described as an imperialist situation at home, as a form of economic, political, and cultural colonialism. The opening of the novel with what we could call a radical and dissident map, that plays the role of paratextual comment and liminal warning, announces an elaborate deconstruction of the then widespread stereotypes about "savage Highlanders", and illustrates Stevenson's redefinition of Highlanders' relationship to their environment. Keywords: Stevenson, Kidnapped, adventure, Map, denunciation.

Nathalie Jaëck est Professeur de littérature britannique xIx ${ }^{\mathrm{e}}$ siècle. Elle est plus particulièrement spécialiste de littérature d'aventure, et notamment de la mutation du genre qui se produit au tournant du siècle. Elle s'intéresse tout spécialement à l'analyse narrative et formelle, à la littérature populaire, au Canon, à la littérature fin de siècle et à ses enjeux spécifiques. Elle a publié plusieurs articles sur Conan Doyle, Dickens, Stevenson, Conrad, Stoker, et deux monographies: Les Histoires de Sherlock Holmes : une affaire d'identité. Bordeaux: Presses Universitaires de Bordeaux: 2008, et Charles Dickens: L'écriture comme pouvoir, l'écriture comme résistance. Bordeaux: Presses Universitaires de Bordeaux: 2008.

Résumé : Dans cet article, je cherche à illustrer le fait que les positions développées par Stevenson dans In the South Seas contre les politiques impérialistes, alors qu'il était installé sur les îles Samoa, trouvent un écho bien plus surprenant dans un roman antérieur, Kidnapped, publié en 1886. J'aimerais prouver que l'on peut lire ce roman écossais comme une dénonciation très documentée de ce que l'auteur considère comme une situation d'impérialisme culturel, économique et politique en Ecosse même. Le fait que le roman s'ouvre sur la présentation d'une carte dissidente et radicale, qui joue un rôle de commentaire paratextuel et d'avertissement liminaire, annonce la déconstruction méthodique des stéréotypes alors très en vogue à propos des «sauvages des Highlands », et illustre la redéfinition que Stevenson propose du rapport des Highlanders à leur environnement. Mots-clés : Stevenson, Kidnapped, aventure, carte, dénonciation. 